\title{
Expressive Tempo Modifications in Adelina Patti's Recordings: An Integrated Approach
}

\author{
MASSIMO ZICARI[1] \\ Scuola Universitaria di Musica, \\ Conservatorio della Svizzera italiana, Lugano
}

\begin{abstract}
This paper explores the extent of expressive tempo modifications as a function of textual content in four operatic arias recorded by Adelina Patti between 1905 and 1906. Their analysis made it possible to determine to what extent significant tempo modifications coincide with those moments in the music, in which special emphasis is demanded by the lyrics. A twofold approach was adopted: the paradigms of historical musicology provided the conceptual tools necessary to define the context, reconstruct the vocal practice, and understand the relationship between the lyrics and the compositional solutions underpinning them; the degree of tempo variability for each aria was determined by empirically measuring the crotchet beat lengths and by calculating the value of mean, mode, standard deviation and coefficient of variation. Results show that Patti's renditions of the four arias present tempo modifications which are instrumental to the expression of their dramatic content, as recommended by the singing methods and treatises which appeared in the course of the nineteenth century. Most crucially, they challenge the assumption that interpreters trained in the late romantic culture abused the composer's intentions and indulged in tasteless, exaggerated interpretive choices.
\end{abstract}

Submitted 2015 November 23; accepted 2016 December 19.

KEYWORDS: vocal style, performance practice, audio recordings

\section{INTRODUCTION}

\section{Expressive Tempo Modifications}

ALTHOUGH early recordings have become the object of increasing scholarly attention, when it comes to discussing issues concerning historically informed performance practice they still represent a problematic body of evidence. Two reasons can account for this: they may challenge the beliefs and convictions we derive from text-based documentary sources (Crutchfield, 1983); we tend to dismiss them on the assumption that interpreters nurtured in the late romantic culture abused the composer's intentions and indulged in tasteless, exaggerated interpretive choices (Limansky, 2004). This article challenges these assumptions and, by analysing four recordings realized by Adelina Patti between 1905 and 1906, investigates whether and to what extent significant tempo modifications occur in the music, where special emphasis is afforded by the lyrics.

Evidence from a number of sources indicates that throughout the nineteenth century soloists tended to indulge in significant changes of tempo. This habit, although accepted as normal by a considerable portion of the concert-going public, came to represent a major concern among those critics who objected to the manner in which, by taking such liberties, performers abused the score and were untrue to the composer's intention (Brown, 1999, pp. 382-383). Richard Wagner played an important role in that regard, for he pushed this tendency to such a degree as to trigger strong critical reactions among both critics and colleagues. In a review which appeared on 5 May 1855 the critic of The Musical World expressed his dislike of the manner in which Wagner invariably took all the second subjects of the symphonic works at a markedly slower pace than the first, and the extent to which crescendi and rallentandi were abused at the expense of the general balance (Zicari, 2014a, pp. 51-64). In 1897 Giuseppe Verdi commented on what he called the comic fashion which had spread among those young conductors who, under the influence of Wagner, used to change the tempo every ten bars and introduce completely new nuances into what he referred to as "every insignificant aria or concert piece" (Conati, 1980, pp. 284-285). 
Notwithstanding Verdi's critical remarks and Wagner's position, in nineteenth century operatic performances tempo modifications were generally considered appropriate when demanded by the expression of a languid or an agitated character. References to modifications over a steady beat as well as larger alterations involving entire phrases or longer sections can be found in many contemporary sources; in some cases they are suggested where changes in dynamics are called for (Toft, 2013, pp. 7984). These changes are generally mentioned in relation to the necessity for the interpreter to express every variety of feeling and sentiment as easily as in speaking, also in the absence of a precise reference to either tempo rubato or any other tempo modification. As Domenico Crivelli put it, a singer should know "the manner of interpreting properly the true and descriptive force of musical figures and their division by means of which the composer displays his genius in adorning poetry with melodies adapted to express every human sentiment" (Crivelli, 1820, p. 89).

Domenico Corri takes into consideration two devices involving a deviation from the regular beat: the "tempo rubato" and the "quickening or retarding of time." "[Tempo rubato] is a detraction of part of the time from one note, and restoring it by increasing the length of another or vice versa; so that, whilst a singer is, in some measure, singing ad libitum, the orchestra, which accompanies him, keeps the time firmly and regularly." The "quickening or retarding of time," instead, encompasses entire phrases or longer passages "in order to give emphasis, energy, by pathos, to particular words". If used with moderation and discretion it represents an improvement, and not an abuse (Corri, 1810, p. 134). Both tempo rubato and larger tempo modifications remained a stable feature and a major means of expression in nineteenth-century Italian opera. In the mid-1850s tempo rubato was described by Manuel Garcia in terms consistent with those used by Corri. Garcia also calls attention to the difference between tempo rubato and the use of accelerando and rallentando. While the first requires that the accents and time of the accompaniment be strictly maintained, in the second the voice and accompaniment must proceed together. The first occurs within a single bar, the second involves longer passages (Garcia, 1857, p. 51). Garcia also clarifies that "Time" can be of three different characters, regular, free and mixed, and that the mixed character is demanded whenever the "feelings expressed in a piece exhibit frequent irregularities of movement, as is often the case in tender, melancholy sentiments" (Garcia, 1857, p. 52). Rallentando is described as a device used to express decrease of passion or as a preparation for the return of a theme or melody; instead, accelerando is used in order to add greater spirit to the general effect. Garcia suggests that a larger degree of expressive liberty both inside a measure and across a longer section finds its justification in the connection that exists between the text and the music. He returns to, and insists upon this notion when dealing with the changes a singer can make by adding ornaments to a melody, the choice of which "must be regulated by the meaning of both words and music" (Garcia, 1857, p. 59). For this reason, the same ornament that would sound appropriate to depict a grandioso sentiment, would be unsuitable when the expression of lighter feelings be demanded. In his Hints on Singing Garcia also remarks that "the works of Donizetti and Bellini contain a great number of passages which, without bearing the sign of the rallentando or accelerando, yet require their use" (Garcia, 1894, p. 62).

Luigi Lablache, in his Complete Method of Singing holds that a student possessed with good taste should observe "the time or the movement indicated by the author at the beginning of the piece, and then the words for which it is composed, and he will know at once what accent must be given to it" (Lablache, n.d., pp. 96-98). Larghetto, Andante, and Andantino, Lablache remarks, "should be sung in a manner either graceful, tender, or mournful, according to the epithet which commonly follows the indication of the movement, and according to the words of the piece" (Lablache, n.d., p. 98). This understanding of the expressive content of a piece represents the basis of good taste.

Only a few years later, Francesco Lamperti lamented that the art of singing lay in a terrible state of decadence, owing to the new and overwhelming tendency to assume a more dramatic character at the expense of true melody. This change resulted in a lamentable condition, as even a strong and sonorous voice sounded monotonous and wanting in the character and dramatic accent required by the lyrics and the quality of the music (Lamperti, 1864, p. ix). Although Lamperti does not make explicit reference to tempo modifications, his Solfeggi are generously supplied with indications such as allargando, stringendo, stentando, col canto, affrettato, rallentando. These are strongly suggestive of a high degree of expressive freedom in the use of tempo, even in the absence of a text. Tempo indications similar to those used by Lamperti can be found in Rossini's Metodo Pratico di Canto Moderno, whose second part includes 12 Nuovi Vocalizzi per Mezzo-soprano o Baritono. Passages bearing indications such as animez toujour or presses may encompass many bars, be followed by a rallentando or lead to a tempo primo section (Rossini, n.d.). In his Complete Method (1894) Enrico Delle Sedie maintains that the execution of those rapid passages that go under the name of agility also require a certain degree of flexibility; the idea with which they are associated should be expressed by means of the rallentando and affrettando, applied to the same phrase (Delle Sedie, 1894, p. 103). 
Nineteenth-century opera singers were encouraged to take interpretive decisions involving tempo modifications whenever these were instrumental to the expression of the sentiments suggested by the lyrics or demanded by the dramatic situation. A good singer was expected to possess a great dramatic talent and, in some cases, this could even compensate for the lack of adequate vocal skills; a case in point in this regard is represented by Mariella Piccolomini, who was said to excel in those qualities that were related primarily to her dramatic force, while many critics found faults with her vocal technique (Zicari, 2014b).

The picture presented thus far did not undergo major changes during the second half of the century, notwithstanding the new dramatized style initiated by Vincenzo Bellini and developed by Giuseppe Verdi (Celletti, 1974). Although in the late 1840s some critics complained bitterly about the shift from proper melody to melodic dramatization (Zicari, 2011), the change in vocal style did not necessarily imply a more rigid approach to expressive tempo. In 1834 Bellini wrote to Francesco Florimo asking him not to observe the metronome markings he had inserted in the score of I Puritani, and to quicken and retard the tempos according to the singers' voice (Cambi, 1943, p. 490). When in 1850 Ernani was revived in London, Henry Fothergill Chorley pointed out that "Verdi's music, in its solo passages and closes, gives him [Sims Reeves] scope for that slackening of tempo and elongation of favourite notes which are considered by 'Young Italy' as the style dramatic" (Chorley, 1850). Chorley made a similar comment when reviewing the London premiere of Rigoletto in 1853: Angiolina Bosio's style suited Verdi's music, for "by him singers are invited, not forbidden, to slacken tempo" (Chorley, 1853). Even though today's scholars tend to agree that Verdi preferred quicker tempos and objected to any arbitrary tempo modifications (Hepokoski, 1985), there seems to be sufficient evidence that it was only the useless modifications that Verdi was opposing, that is to say, those modifications that found no justification in either the lyrics or the dramatic situation (Freitas, 2002). When Verdi conducted his Messa in Köln in 1877 the critic August Guckeisen remarked that the composer indulged in a certain degree of rubato (Conati, 1980, p. 121). On preparing the performance of Verdi's Pezzi sacri in Turin in 1898 the young Toscanini met with the composer, who bestowed on him words of approval for having introduced an allargando that was not marked in the score. Verdi revealed to Toscanini that the reason why the allargando was not there was to avoid the exaggerated expression of that effect (Conati, 1980, p. 292). On other occasions Verdi expressed his aversion to metronomic conducting, as was the case when Toscanini conducted Falstaff in 1899 (Celletti, 1989, p. 160). Although Verdi's scattered declarations seem to add to the idea that he expected his interpreters to be faithful to his intentions, his frequently insisted upon preference for dramatic poignancy encourages a broader understanding of those declarations.

\section{Adelina Patti's Vocal Style}

During a life-long career Adelina Patti (1843-1919) won the admiration of the most severe international critics thanks to the quality of her voice, her dramatic talent and her stylistic versatility. She was soon recognized as a musician endowed with the intelligence necessary to extend her repertoire, assume new dramatic roles and still make a clear distinction between different compositional styles (Cone, 1993). When Patti appeared as Rosina at Covent Garden in 1863, on 11 May the critic of The Times (1863) argued that her richly embellished rendition of the cavatina was justified by the work of many authoritative interpreters before her. Interestingly, upon reviewing her Zerlina on 18 May, the same periodical remarked that she had refrained from adding any embellishment and decided to adhere to Mozart's text with a religious scrupulousness: "not a note is changed, not an ornament or a cadence interpolated" (Royal Italian Opera, 1863). This choice assumes special relevance if we think of other contemporary virtuoso songstresses, who did not share the same attitude, as was the case with Laure Cinti-Damoreau (Caswell, 1975). When Patti made her appearance as Leonora in Verdi's Il Trovatore that year, on 1 June The Times pronounced her a model of excellence both theatrically and vocally (Royal Italian Opera, 1863). In 1863 Patti proved that a properly trained and highly talented singer could master Mozart's Don Giovanni, a model of classical composure, Rossini's Barbiere, a benchmark for the florid belcanto style, and Verdi's new dramatized style with equal success. Years later she was described in quite similar terms by Henry Sutherland Edwards (The Prima Donna, 1888, p. 79), who was impressed by her stylistic flexibility, and Eduard Hanslick (Adelina Patti [1879], 1950, pp. 167-183), who pronounced her equally good when impersonating dramatic roles. In the final stages of her career Patti's high notes had lost the smoothness and strength of her youth. This could not pass unnoticed: "An extra breath here and there; a transposition of a semitone down or maybe two, fewer excursions - and those very 'carefully' managed - above the top line of the treble stave" (Klein, 1920, pp. 354-355). 


\section{The Phonographic Evidence}

The so-called phonographic evidence available to scholars today offers itself as a valuable source of information. Of course, the technologies available at the outset of the development of the recording industry imposed restrictions and constraints of which anyone dealing with an early disc should be aware. Performance speed, just to mention one, still represents a vexatious issue. Notwithstanding the limitations, and although a recording constitutes an artefact that should be understood neither as the performance itself nor as its faithful acoustic representation, a recorded performance can still be investigated successfully, upon condition that the correct textual and contextual coordinates are set.

A number of studies suggest that it is possible to fruitfully investigate the relationship between textual content and musical interpretation in vocal music. Among the most recent, in her analysis of three songs by Franz Schubert, Timmers (2007) explores the influence of performing style and musical structure on the expression of emotions. Timmers takes into consideration a number of recordings spanning the years from 1907 to 1977 and featuring, among others, such prominent artists as Elisabeth Schwarzkopf, Lotte Lehmann and Elena Gerhardt. Results show that, although measuring performance parameters such as duration, amplitude and pitch can be problematic, relative variations in tempo and pitch within a recorded performance are still quite reliable. In particular, she could observe a decrease in variation of bar duration over time within the 20th century. Leech-Wilkinson (2010) analyses the changing style of Elena Gerhardt (1883-1965) as documented in her recordings of Schubert's Lieder (1911-1939) and takes into consideration those expressive gestures that consist of changes in frequency, loudness or duration within or between notes or phrases. Leech-Wilkinson's findings suggest that in Gerhardt's recordings ritardandos at major climaxes could be very large, even in her later performances. This investigation was carried out by measuring the crotchet beat lengths and by calculating range, standard deviation, and skewness values. These values can express meaningful differences in the performances, and suggest well the degree of expressive freedom taken by the performer in question over time. The tendencies observed so far fit well into the picture drawn by Hudson (1997) and Philip (1992), who have also observed that while tempo modifications were a pervasive feature in the second half of the 19th century, their presence decreased meaningfully in the 20th century.

\section{METHOD}

Adelina Patti's discographic legacy consists of twenty-two arias recorded at Craig-y-Nos Castle, in Wales (United Kingdom), between 1905 and 1906 for the Gramophone Company. Four of them were chosen for this investigation: "Voi che sapete" (Nozze di Figaro) and "Batti batti" (Don Giovanni) were recorded in December 1905, while "Ah! non credea mirarti" (La Sonnambula) and "Casta Diva" (Norma) in June 1906. The pianist Landon Ronald accompanied her on the first occasion while her nephew Alfredo Barili accompanied her on the second. In 1905 Patti sang into the small funnel while standing still in one position, and was pulled back when she had to attack a high note; in 1906 she was placed on a small movable platform so that she could be pulled away from or pushed closer to the horn more easily, depending on the loudness of the passage; this was in order to cope with the limited range of dynamics that early phonographs could support (Cone, 1993, pp. 241-248). Since we cannot be sure what speed her records should be played at, it is also difficult to say whether Patti's voice was bright or not (Moran, 1993); nor is it always possible to determine the correct pitch (Leech-Wilkinson, 2009, chapter 4, paragraph 12). The doubt also arises whether in the recordings realized in 1906 the music was transposed a semitone down, as indicated by Klein (1920, p. 355).

The original audio recordings were digitized and made commercially available by Nimbus Records in 1993 (NI 7840/41) and by Historic Masters and EMI Archive in 2006 (HM 500-507A/B Historic Masters) [2]. For this research each performance was transcribed into a two-stave score taking reference from the digital audio track. The upper stave represents as faithful a transcription as possible of what can be heard in the audio track, including ornaments, cadenzas, rhythmic changes, and marks indicating tempo modifications and portamentos. In the absence of sufficient information about the edition Patti may have been reading from, two sources were used for the lower stave: the New Mozart Edition (NMA II/5/16/1-2, p. 175-182; NMA II/5/17:KV 527/12, p. 164-173), and Ricordi's piano reductions of Bellini's operas (plate number 41686, p. 190-191; and 41684, p. 61-69).

In addition to the traditional musicological approach, which involved the analysis of the chosen arias with regard to their dramatic content and musical structure, each audio track was investigated using Sonic Visualizer (Cannam, Landone, \& Sandler, 2010), a software package that allows users to perform a number of measurements and extract the relevant data. In order to quantify tempo modifications the inter-onset intervals were measured by tracking each beat-onset (crotchet) with a marker in the waveform. When the voice and the piano were not perfectly synchronized the onset in the voice was 
considered. In order to improve accuracy, the procedure was performed at reduced playback speed (down to $50 \%$ ). Basic descriptive statistics of the mean, mode and standard deviation of the beat duration were calculated. The beat length values corresponding to the long fermatas were excluded from the calculation, the reason being that a fermata represents a moment of suspension in the unfolding of the musical time, and not a slacking or quickening of tempo for expressive purpose.

\section{RESULTS}

\section{"Voi che sapete" (1905)}

As has been noted, this aria "expresses a sense of insistent, languishing desire, with stronger emotions occasionally adding highlights" (Abert, [1923/24] 2007, p. 951). A closer look at both its text and musical structure helps us understand how Mozart translates the lyrics and their meaning into an aria whose most distinctive character seems to be a harmonic and melodic acceleration towards the final recapitulation. The first two stanzas serve as an introduction to the topic, quasi a captatio benevolentiae addressing both the dramatis personae and the public; Cherubino interrogates Susanna and the Countess about what he feels and, in doing so, spells out the reason why he is so discomforted. The first two stanzas are in $\mathrm{B}_{\mathrm{b}}$ and F Major respectively and present a regular melodic contour, with symmetrical four-bar phrases qualified by a distinctive dactyl-like incipit. In the third stanza a feeling of unrest is introduced, with a sense of languishing desire assuming a prominent role; such words as desir (desire) and diletto (delight) lead to the final martir (martyrdom), for which Mozart makes recourse to a diminished seventh chord. These words, presented in quick succession, are clearly suggestive of the burst in Cherubino's chest. Now he freezes in despair, then he lights up with the fire of passion, then he freezes again (fourth stanza, $\mathrm{A}_{\mathrm{b}}$ Major). Cherubino tries to explain that all this originates from his striving in search of something (love) that he cannot find in himself (fifth stanza, the music moves from $A_{b}$ Major to $g$ minor). A harmonic progression to an anacrusis figure follows (sixth and seventh stanza), which expresses the sobbing and sighing, the trembling and throbbing that qualify Cherubino's languorous unrest (again a diminished seventh chord emphasises the conclusion of the stanza). The aria recapitulates with Cherubino resuming his initial condition, with the first stanza returning together with the initial motivic material.

The analysis of the recording (NI 7841: Cat. 03051, Matrix: 537F) reveals a high degree of freedom with regard to both rhythm and tempo [3]. Patti introduces many changes in the dotted figures in a way that appears to be consistent with what is suggested by Manuel Garcia (1894, p. 50). Many major tempo changes can be also noted; for instance, from the initial beat, where $d=48$, Patti slows

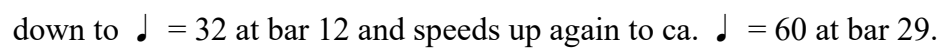

The mean value of the crotchet beat lengths $(\mathrm{N}=137)$ is $1.22 \mathrm{sec} .(\cdot=48)$, which corresponds to the initial beat. The mode value of the beat lengths is also $1.22 \mathrm{sec}$. $(d=48)$, thus suggesting a certain consistency in the chosen tempo. A standard deviation of 0.28 gives us a measure of the internal variability. Although this measure represents a good indicator of the interpreter's moderate expressive freedom, it is the analysis at micro-structural level that provides us with some deeper insight into Patti's interpretive idea. In fact, the micro-differences are consistent with the expressive content of the text, as can be gleaned from Table 1. 
Table 1. The mean beat length and standard deviation values measured for each stanza of Mozart's "Voi che sapete," with lyrical, structural and expressive descriptors.

\begin{tabular}{|c|c|c|c|c|c|c|}
\hline \multicolumn{7}{|c|}{ Measured beat lengths $(\mathrm{N}=137):$ mean value $=1.22 \mathrm{sec} . ;$ mode value $=1.22 \mathrm{sec} . ;$ standard deviation $=0.28$} \\
\hline Bars & Lyrics & $\begin{array}{l}\text { Melodic } \\
\text { structure }\end{array}$ & Key & Expressive content & Metronome & Mean BL \\
\hline $1-12$ & $\begin{array}{l}\text { Voi che sapete } \\
\text { che cosa è amor, } \\
\text { donne, vedete } \\
\text { s'io l'ho nel cor. }\end{array}$ & $\mathrm{A}_{4+4+4}$ & $\mathrm{~B}_{\mathrm{b}}$ & \multirow{2}{*}{$\begin{array}{l}\text { Introduction } \\
\text { (Exordium) }\end{array}$} & Bar 1: $d=48$ & $\begin{array}{c}1.25 \mathrm{sec} . \\
(d= \\
47.8) \\
S D=0.17\end{array}$ \\
\hline $13-20$ & $\begin{array}{l}\text { Quello ch'io provo } \\
\text { vi ridirò; } \\
\text { è per me nuovo, } \\
\text { capir nol so. }\end{array}$ & $\mathrm{B}_{4+4}$ & $\mathrm{~F}$ & & & $\begin{array}{c}1.27 \mathrm{sec} . \\
(d= \\
47.1) \\
S D=0.13\end{array}$ \\
\hline $21-28$ & $\begin{array}{l}\text { Sento un affetto } \\
\text { pien di desir } \\
\text { ch'ora è diletto, } \\
\text { ch'ora è martir. }\end{array}$ & $\mathrm{C}_{4+4}$ & $\begin{array}{l}F \\
f\end{array}$ & $\begin{array}{l}\text { desire, delight, } \\
\text { martyrdom }\end{array}$ & & $\begin{array}{c}1.29 \mathrm{sec} . \\
(d= \\
46.4) \\
S D=0.17\end{array}$ \\
\hline $29-36$ & $\begin{array}{l}\text { Gelo, e poi sento } \\
\text { l'alma avvampar, } \\
\text { e in un momento } \\
\text { torno a gelar. }\end{array}$ & $\mathrm{D}_{4+4}$ & $\mathrm{Ab}_{\mathrm{b}}$ & $\begin{array}{l}\text { Now he freezes, } \\
\text { then he lights up } \\
\text { with fire, then he } \\
\text { freezes again. }\end{array}$ & $\begin{array}{l}\text { Bar 29: } d= \\
60\end{array}$ & $\begin{array}{c}1.10 \mathrm{sec} . \\
(d= \\
54.5) \\
S D=0.12\end{array}$ \\
\hline $37-44$ & $\begin{array}{l}\text { Ricerco un bene } \\
\text { fuori di me, } \\
\text { non so chi 'l tiene, } \\
\text { non so cos'è. }\end{array}$ & $\mathrm{E}_{4+4}$ & $\begin{array}{l}\mathrm{Ab}_{\mathrm{b}} \\
\mathrm{g}\end{array}$ & $\begin{array}{l}\text { Looking for } \\
\text { something, } \\
\text { sense of unrest }\end{array}$ & $\begin{array}{l}\text { Bar 37: } d= \\
62\end{array}$ & $\begin{array}{l}1.07 \mathrm{sec} . \\
(d=56) \\
S D=0.16\end{array}$ \\
\hline $45-48$ & $\begin{array}{l}\text { Sospiro e gemo } \\
\text { senza voler, } \\
\text { palpito e tremo } \\
\text { senza saper, }\end{array}$ & $\mathrm{F}_{2+2+2}$ & $\begin{array}{l}\text { Harmonic } \\
\text { progression }\end{array}$ & $\begin{array}{l}\text { The sobbing and } \\
\text { sighing, the } \\
\text { trembling and } \\
\text { throbbing of love. }\end{array}$ & $\begin{array}{l}\text { Bar 44: } \\
\text { animando } \\
\text { Bar 46: d = } \\
84\end{array}$ & $\begin{array}{c}0.82 \mathrm{sec} . \\
(\downarrow= \\
73.4) \\
S D=0.06\end{array}$ \\
\hline $49-53$ & $\begin{array}{l}\text { non trovo pace } \\
\text { notte né dì: } \\
\text { ma pur mi piace } \\
\text { languir così. }\end{array}$ & $\mathrm{G}_{4}$ & $\begin{array}{l}\text { (diminished } \\
\text { seventh on } \\
\text { languir) }\end{array}$ & $\begin{array}{l}\text { Sense of unrest, } \\
\text { ambiguously un- } \\
\text { pleasant. }\end{array}$ & $\begin{array}{l}\text { Molto rit. } \\
\text { Bar 53: } \quad= \\
28\end{array}$ & $\begin{array}{c}1.45 \mathrm{sec} . \\
(d= \\
41.4) \\
S D=0.39\end{array}$ \\
\hline $54-69$ & $\begin{array}{l}\text { Voi che sapete } \\
\text { che cosa è amor, } \\
\text { donne, vedete } \\
\text { s'io l'ho nel cor. }\end{array}$ & $\mathrm{A}_{4+4+4+4}$ & $\mathrm{Bb}$ & Recapitulation & $\begin{array}{l}\text { Bar 54: d = } \\
33 \\
\text { Bar 58: d = } \\
57\end{array}$ & $\begin{array}{c}1.19 \text { sec. } \\
(d= \\
50.3) \\
S D=0.20\end{array}$ \\
\hline
\end{tabular}

Notwithstanding some small modifications, Patti's tempo remains stable in the first three stanzas (bars 1-28); no sooner does she approach the fourth one than she speeds up in a manner consistent with the sense of agitation suggested by the words. Patti is consistent with the lyrics also within this section, for on the words "torno a gelar (and again I freeze)" she slows down considerably. The tempo increases again after bar 37, reaches the climax in the sobbing and sighing section (bars 45-48), to calm down when Cherubino indulges in his amorous languor. However, if we look at each single stanza, we notice that tempo variability tends to decrease as speed values increase. If we consider bars $45-48$ we notice that although this is the fastest and most agitated section in the entire piece, the internal standard deviation value is the lowest $(S D=0.06)$. On the other hand, when we look at bars $49-53$ we find that the lowest speed $(\cdot=41.4)$ goes together with the highest standard deviation value $(S D=0.39)$. This tendency is observable across the whole aria, as the moderate negative correlation measured between the metronome and the standard deviation values shows: $r=-0.71$ (Pearson).

At bar 54 Patti takes a slower tempo than at the beginning; however, the entire reprise is at a slightly quicker pace than the opening section and the standard deviation value approximates the initial one $(S D=0.20)$. One further element appears to be distinctive in Patti's interpretation, that is the emphasis on the semiquaver passages, where she slows down remarkably, leaving it to the pianist to 
catch up with the initial pace. As some critics observed already in 1863, Patti's recording presents no newly inserted bravura passages, in contrast to Cinti-Damoreau's interpretation (Caswell, 1989).

\section{"Batti, batti" (1905)}

In "Batti, Batti” from Act I, Scene V of Mozart's Don Giovanni, Zerlina pleads with Masetto to beat her if he wants. She declares herself ready to bear the blows he will lay on her and to kiss gladly his dear hands. Although Zerlina did not fall into Don Giovanni's trap, she appears to have been hesitant at first, and would have conceded herself to the man had Donna Elvira not intervened. Zerlina is now using all her feminine tricks to seduce Masetto, "to ensnare him with a tenderness of bewitching charm, an inspired mixture of genuine affection and the most cunning calculation" (Abert, [1923/24] 2007, pp. 1075-76). The aria consists of three stanzas which translate musically into two parts: the "Andante grazioso" in 2/4 and the "Allegretto" in 6/8. To set this dramatic situation to music Mozart relies on a simple melodic device, a descending diatonic figure followed by some pleading chordal intervals. As Abert argues, this suggests Zerlina's physical gesture of seductively stroking Masetto's cheek. The whole first part is constructed on a regular four-bar melodic structure that moves from $\mathrm{F}$ to $\mathrm{C}$ Major with no unexpected harmonic change or deviation. The reprise (bar 36) presents a melodic variation, for the descending quaver figures are now changed into semiquavers, a modification that suggests a sense of intensification of the initial stroking gesture. The dance-like Allegretto in $6 / 8$ unfolds rapidly towards the final happy ending.

In Patti's recording (NI 7840: Cat. 03055, Matrix 541F) the beat length values were measured for the Andante $(\mathrm{N}=119)$ and the Allegretto $(\mathrm{N}=72)$ respectively. A first glance at the figures suggests a certain degree of stability in the tempo (Table 2). In the Andante the mean value of the crotchet beat lengths is $1.16 \mathrm{sec}$. (\rfloor$=51.7)$, to which the mode is extremely close: $1.17 \mathrm{sec} .(+=51.3)$. This, again, suggests a steady tempo, while a standard deviation of 0.17 gives us a measure of the relatively low internal variability. The third stanza of the Andante, bars 37-60, is characterized by a stronger sense of unrest; this translates into a gradual increase in speed (bars $40-46)$ that reaches its highest value at bar $46(d=65)$. At the same time, in the third stanza the highest mean speed value $(d=56.1)$ goes together with the lowest variability $(S D=0.10)$. In the Allegretto, where the mean beat length value is $0.72 \mathrm{sec}$. ( $\downarrow=83.3)$, the mode value is $0.68 \mathrm{sec} .(\rfloor=88)$, and the standard deviation is 0.16 , a clear understanding of the data is more problematic. This is owing to a certain sense of fatigue in Patti's rendition, particularly evident in bars 69-70, where she even drops a few notes in order to breath more comfortably. 
Table 2. The mean beat length and standard deviation values measured for each stanza of both the Andante and the Allegretto of Mozart's "Batti, batti," with lyrical, structural and expressive descriptors.

\begin{tabular}{|c|c|c|c|c|c|c|}
\hline \multicolumn{7}{|c|}{ Beat length values (crotchet) measured for the Andante $(\mathrm{N}=119)$ and the Allegretto $(\mathrm{N}=72)$ : } \\
\hline \multicolumn{4}{|c|}{$\begin{array}{l}\text { Andante }(\text { bars } 1-60) \\
\text { mean value }=1.16 \mathrm{sec} . \\
\text { mode value }=1.17 \mathrm{sec} \\
\text { standard deviation }=0.17\end{array}$} & \multicolumn{3}{|c|}{$\begin{array}{l}\text { Allegretto }(\text { bars } 61-96) \\
\text { mean value }=0.72 \mathrm{sec} \\
\text { mode value }=0.68 \mathrm{sec} \\
\text { standard deviation }=0.16\end{array}$} \\
\hline Bars & Lyrics & $\begin{array}{l}\text { Melodic } \\
\text { structure }\end{array}$ & $\begin{array}{l}\text { Key } \\
\text { meter }\end{array}$ & $\begin{array}{c}\text { Expressive } \\
\text { content }\end{array}$ & $\begin{array}{l}\text { Metronome } \\
\text { (Patti) }\end{array}$ & Mean BL \\
\hline $1-16$ & $\begin{array}{l}\text { Batti, batti, o bel Masetto, } \\
\text { la tua povera Zerlina: } \\
\text { starò qui come agnellina } \\
\text { le tue botte ad aspettar. }\end{array}$ & $\begin{array}{l}\mathrm{A}_{4+4} \\
\mathrm{~A}^{1} 4+4\end{array}$ & $\mathrm{~F}(2 / 4)$ & $\begin{array}{l}\text { Affection and } \\
\text { seductiveness }\end{array}$ & $\begin{array}{l}\text { Bar 1: } d=34 \\
\text { Bar 3: } d=52\end{array}$ & 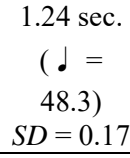 \\
\hline $17-36$ & $\begin{array}{l}\text { Lascierò straziarmi il crine, } \\
\text { lascierò cavarmi gli occhi, } \\
\text { e le care tue manine } \\
\text { lieta poi saprò baciar. }\end{array}$ & $\begin{array}{l}\mathrm{B}_{4+4} \\
\mathrm{~B}_{4+4+4}^{1}\end{array}$ & $\mathrm{C}$ & $\begin{array}{l}\text { A more } \\
\text { decided } \\
\text { gesture }\end{array}$ & $\begin{array}{l}\text { Bar 33: } \cdot= \\
29 \\
\text { Bar 36: } \cdot= \\
52\end{array}$ & 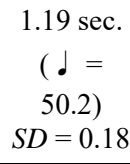 \\
\hline $37-60$ & $\begin{array}{l}\text { Batti, batti, o bel Masetto, } \\
\text { la tua povera Zerlina: } \\
\text { starò qui come agnellina } \\
\text { le tue botte ad aspettar. } \\
\text { Ah lo vedo, non hai core. }\end{array}$ & $\begin{array}{l}\mathrm{A}_{4+4} \\
\mathrm{~A}^{1}{ }_{4+4} \\
\mathrm{Coda}_{4+4}\end{array}$ & F & $\begin{array}{l}\text { Affection and } \\
\text { seductiveness } \\
\text { that moves } \\
\text { towards a } \\
\text { sense of } \\
\text { unrest }\end{array}$ & $\begin{array}{l}\text { Bar 42: d = } \\
61 \\
\text { Bar 46: d = } \\
65 \\
\text { Bar 52: d = } \\
49\end{array}$ & $\begin{array}{c}1.07 \mathrm{sec} . \\
(\downarrow= \\
56.1) \\
S D=0.10\end{array}$ \\
\hline $61-96$ & $\begin{array}{l}\text { Pace, pace, o vita mia; } \\
\text { in contenti ed allegria } \\
\text { notte e dì vogliam passar. }\end{array}$ & Allegretto & $\mathrm{F}(6 / 8)$ & $\begin{array}{l}\text { jubilant } \\
\text { happiness }\end{array}$ & $\begin{array}{l}\text { Bar 61: d = } \\
90\end{array}$ & 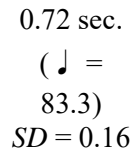 \\
\hline
\end{tabular}

Although Patti adopts a steady tempo and refrains from large modifications, as the mood of the aria suggests, she emphasises the sense of impatience and anticipation that grows along the second part of the Andante making small rhythmical changes.

\section{“Ah! non credea mirarti" (1906)}

The aria belongs to the final scene of Vincenzo Bellini's La sonnambula (1831), where the mystery that surrounds Amina is clarified. Her marriage to Elvino has been almost definitively compromised by her disease, since she has been seen sleepwalking into a man's room, and therefore believed guilty by the whole village. In the final scene Amina is sleepwalking again, this time on the high, dangerously unstable mill bridge, whence all the peasants can see her. She looks at the flower(s) Elvino has given her, and utters words of deep sorrow, for her love has proven to be as ephemeral and short-lived as the dry flower she is now holding (first stanza). Her tears can perhaps revive the flower, but they cannot revive love (second stanza).

Amina's aria defies the conventional structure of the Italian lyric form, where a first pair of fourbar phrases $\left(\mathrm{A}_{4} \mathrm{~A}_{4}{ }^{1}\right)$ is followed by a contrasting medial four-bar phrase $\left(\mathrm{B}_{4}\right)$, which either leads back to the initial melodic material $\left(\mathrm{A}_{4}\right)$ or to a new closing four-bar phrase $\left(\mathrm{C}_{4}\right)$ (Huebner, 1992; Adamo \& Lippmann, 1981, pp. 428-429). Instead, Amina's aria combines phrases of different lengths that move from a minor to C Major (Zoppelli, 1996; Adamo \& Lippmann, 1981, p. 484). The first stanza is set to a four-bar phrase followed by a five-bar phrase that is prolonged by two more bars. The two following four-bar phrases comprising Elvino's pertichini are not present in Patti's recording. In the second stanza a four-bar phrase in C Major is followed by a contracted three-bar phrase leading to the final cadenza through six more bars, which set to music the opening lines ("Ah! non credea"). In the bridge section a shift from a minor to C Major occurs which, according to the contemporary conventions, should find its justification in as distinct a change in the emotional content of the text, for example from sadness to 
joyfulness. It is not the case. Amina is not any happier than before; she rather expresses resignation, since her sorrowful tears can do nothing to change her destiny (at least apparently). However, while she expresses her grief in a state of unconsciousness, all the villagers are watching her. Amina's sleepwalking in front of the passers-by proves her innocence, and her words testify to her immaculate love. Therefore, the key change in the music may find its justification in the external conditions of the scene. Since the nature of Amina's disease is now made known to everybody and her virginal virtue is no longer in question, Elvino will marry her.

Patti's interpretation (NI 7841: Cat. 03084; Matrix 683F) features such a high degree of variability that it is almost impossible to ascertain the correct metronome value. The measured beat length values $(\mathrm{N}=102)$ result in a quite spread out data set; the distance between the mode $(1.01 \mathrm{sec}$; $d=$ $59.3)$ and the mean values ( $1.39 \mathrm{sec}$; $\quad$ J = 43.6) is large, the standard deviation is 0.68 , which suggests a relatively high degree of internal variability. The entire first part is a little faster $(\bullet=46)$ and steadier $(S D=0.58)$ than the second, where speed decreases $\left({ }^{\prime}=39\right)$ but the standard deviation value raises to 0.74 (Table 3). As already observed in Mozart's arias, Patti takes advantage of the slower pace to indulge in a more nuanced interpretation.

Table 3. The mean beat length and standard deviation values measured for each stanza of Bellini's "Ah! non credea mirarti," with lyrical, structural and expressive descriptors.

\begin{tabular}{|c|c|c|c|c|c|c|}
\hline \multicolumn{7}{|c|}{$\begin{array}{l}\text { Measured values in "Ah! non credea mirarti" }(\mathrm{N}=102) \\
\text { Beat length mean }=1.39 \text { sec.; beat length mode }=1.01 \text { sec.; standard deviation }=0.68\end{array}$} \\
\hline Bar & Lyrics & $\begin{array}{l}\text { Melodic } \\
\text { structure }\end{array}$ & Key & $\begin{array}{l}\text { Expressive } \\
\text { content }\end{array}$ & $\begin{array}{l}\text { Metronome } \\
\text { (Patti) }\end{array}$ & $\begin{array}{l}\text { Mean BL } \\
\text { and } S D\end{array}$ \\
\hline $1-13$ & $\begin{array}{l}\text { Ah! non credea mirarti } \\
\text { sì presto estinto, o fiore; } \\
\text { passasti al par d'amore, } \\
\text { che un giorno sol durò. } \\
\text { (piange sui fiori) }\end{array}$ & $\mathrm{A}_{4+5+2}$ & a minor & $\begin{array}{l}\text { Sorrow and } \\
\text { sadness for the } \\
\text { lost short-lived } \\
\text { love }\end{array}$ & $\begin{array}{l}\text { Bar } 1 \cdot= \\
60\end{array}$ & $\begin{array}{l}1.30 \mathrm{sec} . \\
(\downarrow=46) \\
S D=0.58\end{array}$ \\
\hline $13-26$ & $\begin{array}{l}\text { Potria novel vigore } \\
\text { Il pianto mio recarti... } \\
\text { Ma ravvivar l'amore } \\
\text { il pianto mio non può. } \\
\text { (Ah! non credea...) }\end{array}$ & $\begin{array}{r}\mathrm{B}_{4+3} \\
6+2\end{array}$ & C Major & $\begin{array}{l}\text { Hope and } \\
\text { resignation, for } \\
\text { tears cannot } \\
\text { revive love. }\end{array}$ & $\begin{array}{l}\text { Bar } 13 \cdot d= \\
50\end{array}$ & $\begin{array}{l}1.55 \mathrm{sec} . \\
\left(\begin{array}{l}d=39) \\
S D=0.74\end{array}\right.\end{array}$ \\
\hline
\end{tabular}

Patti changes all the dotted figures into triplets, a change that makes the entire aria sound as if it had been written in a different time signature (12/8). Virtually all the descending figures are taken at a slower tempo, so as to assume a sobbing, sorrowful character. In addition to the ubiquitous portamentos, Patti enriches the score with a number of grace notes, a short internal cadenza, a passaggio at bar 14, and a chromaticism at bar 16 (Figure 1 in the appendix). However, her ornamented version appears to be quite discreet when compared to Jenny Lind's notated version (Caswell, 1989).

\section{"Casta Diva" (1906)}

In the Cavatina "Casta Diva, che inargenti" (Act I, scene 4) from Bellini's Norma (1831) the priestess of the Druids celebrates a religious ceremony dedicated to the Moon. Oroveso, Norma's father, asks whether they should not rise in arms against the Romans but Norma, also owing to her clandestine relation with Pollione, insists that it is not yet time. Then Norma approaches the altar with a plea to the "Chaste Goddess." In the first stanza Norma asks the Goddess to turn her unclouded and unveiled semblance onto the Druids; in the second she pleads with the Goddess to temper the Druids' ardent spirits and scatter on the earth the peace that reigns in the sky. It is a moment of prayer, with Norma standing in front of the kneeled Druids, her arms spread open to the sky. The music consists of two main sections, each corresponding to a different stanza. The melody presents an extended version of the lyric form; the $\mathrm{A}_{4} \mathrm{~A}_{4}^{1} \mathrm{~B}_{4} \mathrm{C}_{4}$ structure is followed by two phrases $\left(\mathrm{D}_{4} \mathrm{D}_{4+1}\right)$, which, on a dominant seventh chord, lead to the second stanza and the repeat of the entire first section. The customary final cadenza closes the aria. The initial melody in F Major moves to $d$ minor in the medial section $\left(D_{4} D_{4+1}\right)$, where a certain degree of harmonic instability can be observed. The home key is resumed upon the conclusion of the medial section. The pleading quality of the aria is emphasized by the shift from major to minor key, first when 
the priestess asks the Moon to turn her eye on the Druids, and then when she asks her to scatter her peace on the earth.

In the recording (HM 506A: Cat. 03082, Matrix: 681c) Patti tends to round up the semiquavers into quavers in the second part of each phrase. The moments in which she is not in synchrony with the piano are numerous, this is owing at least in part to the frequent breaths she takes. Many other modifications in the rhythm can be noted, together with the use of ornamentation and the extended final cadenza.

Patti's interpretation features a moderate degree of freedom, as the measured beat length values $(\mathrm{N}=156)$ suggest; the beat length mean $(1.21 \mathrm{sec} . ; .=50)$ and mode $(1.25 \mathrm{sec} . ; .+.=48)$ values are quite close to each other, and the standard deviation is 0.32 (Table 4). A lower standard deviation value $(S D=0.29)$ and a faster tempo $\left(J^{\prime}=50.3\right)$ can be observed in the second stanza, possibly as a consequence of a slightly different dramatic quality of the text (pleading).

Table 4. The mean beat length and standard deviation values measured for each stanza of Bellini's "Casta Diva," with lyrical, structural and expressive descriptors.

\begin{tabular}{|c|c|c|c|c|c|c|}
\hline \multicolumn{7}{|c|}{$\begin{array}{c}\text { Measured values in "Casta Diva" }(\mathrm{N}=156) \\
\text { mean }=1.21 \mathrm{sec} . ; \text { mode }=1.25 \mathrm{sec} . ; \text { standard deviation }=0.32\end{array}$} \\
\hline $\begin{array}{l}\text { Bar } \\
\text { number }\end{array}$ & Lyrics & $\begin{array}{l}\text { Melodic } \\
\text { structure }\end{array}$ & Key & $\begin{array}{l}\text { Expressive } \\
\text { content }\end{array}$ & Metronome & Mean BL \\
\hline $1-25$ & $\begin{array}{l}\text { Casta Diva che inargenti } \\
\text { Queste sacre antiche piante, } \\
\text { A noi volgi il bel sembiante } \\
\text { Senza nube e senza vel. }\end{array}$ & $\begin{array}{l}\mathrm{A}_{4} \mathrm{~A}^{1}{ }_{4} \\
\mathrm{~B}_{4} \mathrm{C}_{4} \\
\mathrm{D}_{4} \mathrm{D}^{1}{ }_{4+1}\end{array}$ & $\begin{array}{l}\text { F Major } \\
\text { d minor } \\
\text { F Major } \\
\left(\mathrm{V}^{7}\right)\end{array}$ & $\begin{array}{l}\text { Invocation to } \\
\text { the Moon: } \\
\text { turn your eye } \\
\text { upon us }\end{array}$ & $\begin{array}{l}\text { Bar } 1 \\
\qquad .=55\end{array}$ & $\begin{array}{c}1.21 \mathrm{sec} . \\
(d .= \\
49.7) \\
S D=0.34\end{array}$ \\
\hline $26-43$ & $\begin{array}{l}\text { Tempra tu de' cori ardenti, } \\
\text { Tempra ancor lo zelo audace, } \\
\text { Spargi in terra quella pace } \\
\text { Che regnar tu fai nel ciel }\end{array}$ & $\begin{array}{l}\mathrm{A}_{4} \mathrm{~A}_{4}^{1} \\
\mathrm{~B}_{4} \mathrm{C}_{4+2}\end{array}$ & $\begin{array}{l}\text { F Major } \\
\text { d minor } \\
\text { F Major }\end{array}$ & $\begin{array}{l}\text { Pleading with } \\
\text { the Moon to } \\
\text { temper the } \\
\text { Druids' ardent } \\
\text { spirit }\end{array}$ & $\begin{array}{l}\text { Bar } 26 \\
\cdot=55\end{array}$ & $\begin{array}{c}1.19 \text { sec. } \\
(d .= \\
50.3) \\
S D=0.29\end{array}$ \\
\hline
\end{tabular}

A pattern can be recognized in bars 1-8, where each semi-phrase closes with a slight ritardando (Figure 2 in the appendix). The same can be observed in bars 26-33, where longer and more frequent breaths result in a more pronounced sense of fatigue. At bar 39 Patti inserts a ritardando that leads to the final cadenza. Although it is not possible to ascertain to what extent these modifications depend on the physical strain put on Patti's voice (Patti was in her sixties when she recorded these arias), stylistic consistency is evident in the manner in which she divides each single phrase and emphasises the pleading quality in the descending passages.

\section{DISCUSSION}

Although expressive features such as a pervasive portamento and continuous vibrato appear to be characteristic of Patti's vocal technique, the manner in which she modifies the tempo differs in relation to the dramatic content of each aria. This becomes all the more clear if we take into consideration the coefficient of variation value calculated for each of the four arias (Table 5).

Table 5: Patti's measured coefficient of variation values for each aria taken into consideration.

\begin{tabular}{|c|c|c|c|c|c|}
\hline & $\begin{array}{c}\text { "Voi che sapete" } \\
(1905)\end{array}$ & \multicolumn{2}{|c|}{$\begin{array}{c}\text { "Batti, batti" } \\
(1905)\end{array}$} & $\begin{array}{c}\text { "Ah! non credea" } \\
(1906)\end{array}$ & $\begin{array}{l}\text { "Casta Diva" } \\
(1906)\end{array}$ \\
\hline $\begin{array}{l}\text { Tempo } \\
\text { indication }\end{array}$ & Andante $(\cdot=49)$ & $\begin{array}{l}\text { Andante } \\
(\cdot=51)\end{array}$ & $\begin{array}{l}\text { Allegretto } \\
(\cdot=83)\end{array}$ & $\begin{array}{c}\text { Andante cantabile } \\
(\quad(=44)\end{array}$ & $\begin{array}{l}\text { Andante sost. } \\
\text { assai }(\cdot=50)\end{array}$ \\
\hline $\begin{array}{l}\text { Coefficient } \\
\text { of variation }\end{array}$ & 0.32 & 0.15 & 0.23 & 0.46 & 0.26 \\
\hline
\end{tabular}

The coefficient of variation values suggest a different degree of internal variability for each aria, whether romantic or classical; most crucially, and regardless of the style, a comparably higher variability is observable in those arias where the lyrics express either an internal struggle ("Voi che sapete:" $C V=$ 
0.32 ) or a sobbing hopelessness (“Ah! non credea:" $C V=0.46$ ). By contrast, the arias characterized by a more uniform emotional quality ("Batti, batti" and "Casta Diva") present a lower degree of internal variability. This is especially relevant if we consider that arias bearing similar tempo indications (Andante) and featuring a relatively close tempo mean value $(~ d=50 \mathrm{ca}$.) may still differ meaningfully with regard to internal variability. As already mentioned, the Allegretto in "Batti, batti" represents a problematic case, for Patti's struggle to cope with the most demanding technical passages might have affected the measured tempo variability.

However, although the values shown in the table represent a good indicator of Patti's interpretative orientations it is the analysis at micro-structural level that provides us with more in-depth information. In Mozart's "Voi che sapete," the long text presents a number of well-chosen verbal expressions, each of which offers itself as an unmissable opportunity for the interpreter willing to convey that sense of languishing desire emphasized by the music. In Patti's rendition, the most dramatic interpretive choices are to be found at bars 45-53, where the measured values range from the fastest and most straight-forward (\rfloor$=73.4 ; S D=0.06)$ to the slowest and most nuanced (\rfloor$=41.4, S D=0.39)$. In "Batti, batti" the manner in which Zerlina's stroking gesture may guide the singer towards the most appropriate expressive choice is also more evident at microstructural level. In fact, even though the standard deviation value does not suggest a high degree of variability $(S D=0.17)$ and the mean and mode beat length values are quite close $(1.16 \mathrm{sec}$. and $1.17 \mathrm{sec}$.$) , the beat length value may still range from$ 2.05 sec. (\rfloor$=29$ at bar 33$)$ up to 0.92 sec. (\rfloor$=65$ at bar 46$)$. In Bellini's "Ah! non credea mirarti," the sobbing quality of the text translates into Patti slowing down at the end of each semi-phrase; upon the conclusion of the aria she literally drags herself along, thus translating hope and resignation into a very slow tempo (\rfloor$=39)$ and the highest degree of variability $(S D=0.74)$. To a limited extent, something similar can be observed in "Casta Diva," especially in the first section, where the pleading character is predominant $\left(\mathrm{J}_{\mathrm{S}}=49.7 ; S D=0.34\right)$. As these figures suggest, an increase in variability is generally associated with a slower tempo within a single aria.

Furthermore, if assessing intra-subjective consistency may help profile an interpreter in relation to arias of different dramatic content and compositional style, inter-subjective consistency for a single aria can be fruitfully investigated by comparing the measured values among larger groups of singers belonging to either the same or a different period. The evolution of tempo variability could be further explored using correlation analysis - both linear (Pearson) and non-linear (Spearman) - as well as linear regression analysis. Upon condition that a sufficiently large sample size be reached, a short panel regression model (i.e. a statistical model based on repeated information for the same individual over time) could be built; this would allow investigating the evolution of tempo variability over time while accounting for specific stylistic traits characterizing individual singers.

\section{CONCLUSIONS}

Although limited in sample size, these findings confirm that a quantitative approach to tempo variability in recorded performances may help shed new light on an interpretive feature that was - and still is - of pivotal importance when it comes to defining a singer's personal style. In fact, a number of details can be gleaned from the empirical analysis of tempo profiles at both macro- and micro-structural level. The versatility for which Patti was so praised during her life-long career finds confirmation in the figures discussed so far; her careful reading of the dramatic texts results in interpretive choices that are consistent with the recommendations of contemporary singing methods.

\section{Acknowledgements}

I would like to thank Emiliano Soldini for his priceless help with the analysis of the data and the descriptive statistics, and Giulia Nuti for her precious assistance with the English language. I am also grateful to Dorottya Fabian for her invaluable advice and critical feedback.

\section{NOTES}

[1] Correspondence can be addressed to Massimo Zicari, Deputy Head of Research, Conservatorio della Svizzera italiana, Via Soldino 9, CH-6900 Lugano (Switzerland) email: massimo.zicari@conservatorio.ch. 
[2] The Nimbus Records edition was used for the first three arias, while the Historic Masters edition was used for the last ("Casta Diva").

[3] A transcription of the same aria can be found in Brown (1999, p. 437), where the tempo modifications are not indicated, in Freitas (2002, p. 251), who reports only a portion of the entire aria, and in Toft (2013, p. 235). Toft analyses Patti's rendition by taking reference from the ornamented version that can be found in a manuscript copy that dates back to $1798 \mathrm{ca}$., and is preserved at the British Library (Add. MS 50185, fol. 28r).

\section{REFERENCES}

Abert, H. ([1923/24] 2007). W.A. Mozart. (C. Eisen, Ed., \& S. Spencer, Trans.) New Haven \& London: Yale University Press.

Adamo, M. R., \& Lippmann, F. (1981). Vincenzo Bellini. Torino: ERI.

Brown, C. (1999). Classical \& Romantic Performance Practice 1750-1900. Oxford: Oxford University Press. https://doi.org/10.1093/acprof:oso/9780198161653.001.0001

Cambi, L. (1943). Vincenzo Bellini. Epistolario. Milano: Mondadori.

Cannam, C., Landone, C., \& Sandler, M. (2010). Sonic Visualiser: An Open Source Application for Viewing, Analysing, and Annotating Music Audio Files. Proceedings of the ACM Multimedia 2010 International Conference. Florence. https://doi.org/10.1145/1873951.1874248

Caswell, A. (1975). Mme Cinti-Damoreau and the Embellishment of Italian Opera in Paris: 1820-1845. Journal of the American Musicological Society, 28(3), 459-492. https://doi.org/10.2307/831318

Caswell, A. (Ed.). (1989). Embellished Opera Arias (Vols. VII-VIII). Madison, Wisconsin, USA: A-REditions.

Celletti, R. (1974). Caratteri della vocalità di Verdi. Atti del III Congresso Internazionale di Studi Verdiani, (pp. 81-88). Parma.

Celletti, R. (1989). Il canto. Vallardi.

Chorley, H. F. (1850, March 23). Her Majesty's Theatre. The Athenaeum, p. 320.

Chorley, H. F. (1853, May 21). Royal Italian Opera. The Athenaeum, p. 625.

Conati, M. (Ed.). (1980). Interviste e Incontri con Verdi. Formichiere.

Cone, J. F. (1993). Adelina Patti Queen of Hearts. Portland, Oregon, USA: Amadeus Press.

Corri, D. (1810). The Singer's Preceptor. London: Chappell \& C.

Crivelli, D. (1820). L'Arte del Canto. London.

Crutchfield, W. (1983). Vocal Ornamentation in Verdi: The Phonographic Evidence. 19th-Century Music, 7(1), 3-54. https://doi.org/10.2307/746545

Delle Sedie, E. (1894). A Complete Method of Singing. New York: Schirmer.

Edwards, H. S. (1888). The Prima Donna (Vol. II). London: Remington and Co. 
Freitas, R. (2002). Towards a Verdian Ideal of Singing: Emancipation from Modern Orthodoxy. Journal of the Royal Musical Association, 127(2), 226-257. https://doi.org/10.1093/jrma/127.2.226

Garcia, M. (1857). Garcia's New Treatise on the Art of Singing. London: 1894.

Garcia, M. (1894). Hints on Singing. New York: Edward Schuberth.

Hanslick, E. (1950). Adelina Patti [1879]. In Music Criticisms 1846-99 (H. Pleasants, Trans., pp. 167183). Harmondsworth: Penguin Books.

Hepokoski, J. (1985). Under the Eye of the Verdian Bear: Notes on the Rehearsals and Première of "Falstaff". The Musical Quarterly, 71(2), 135-156. https://doi.org/10.1093/mq/LXXI.2.135

Hudson, R. (1997). Stolen Time: The History of Tempo Rubato. Oxford: Clarendon Press.

Huebner, S. (1992). Lyric Form in 'Ottocento' Opera. Journal of the Royal Musical Association, 117(1), 123-147. https://doi.org/10.1093/jrma/117.1.123

Klein, H. (1920). The Reign of Patti. London: Fisher Unwin.

Lablache, L. (n.d.). Complete method of singing; or, A rational analysis of the principles according to which the studies should be directed for developing the voice. Philadelphia: Ditson \& Co.

Lamperti, F. (1864). Guida teorico-pratica-elementare per lo studio del canto. Milano: Ricordi.

Leech-Wilkinson, D. (2009). The Changing Sound of Music: Approaches to Studying Recorded Musical Performance. London: CHARM.

Leech-Wilkinson, D. (2010). Performance Style in Elena Gerhardt's Schubert Song Recordings. Musicae Scientiae, 14(2), 57-84. https://doi.org/10.1177/102986491001400203

Limansky, N. E. (2004). Luisa Tetrazzini Coloratura Secrets. The Opera Quarterly, 20(4), 540-569. https://doi.org/10.1093/oq/kbh076

Moran, W. R. (1993). The Recorded Legagy of Adelina Patti. In J. F. Cone, Adelina Patti Queen of Hearts (pp. 305-316). Portland: Amadeus Press.

Philip, R. (1992). Early Recordings and Musical Style Changing Tastes in Instrumental Performance, 1900-1950. Cambridge: Cambridge University Press. https://doi.org/10.1017/CBO9780511470271

Rossini, G. (n.d.). Metodo pratico di canto moderno. Berlin: Schlesinger.

Royal Italian Opera. (1863, June 1). The Times, p. 12.

Royal Italian Opera. (1863, May 18). The Times, p. 12.

Royal Italian Opera. (1863, May 11). The Times, p. 12.

Timmers, R. (2007). Vocal Expression in Recorded Performances of Schubert songs. Musicae Scientiae, 11(2), 237-268. https://doi.org/10.1177/102986490701100205

Toft, R. (2013). Bel Canto: a Performer's Guide. Oxford: Oxford University Press.

Zicari, M. (2011). La prima recezione di Giuseppe Verdi a Londra: Henry Fothergill Chorley e 1'Athenaeum. Schweizer Jahrbuch für Musikwissenschaft (31), 27-60.

Zicari, M. (2014a). Verdi and Wagner in Early Victorian London: The Viewpoint of the "Musical World". Studia UBB Musica, 59(1), 51-64. 
Zicari, M. (2014b). Un caso di moralità. La Traviata nella Londra Vittoriana (1856). Musica/Realtà(103), $141-157$.

Zoppelli, L. (1996). L'Idillio Borghese. In C. Chiarot (Ed.), La Sonnambula (pp. 49-62). Venezia.

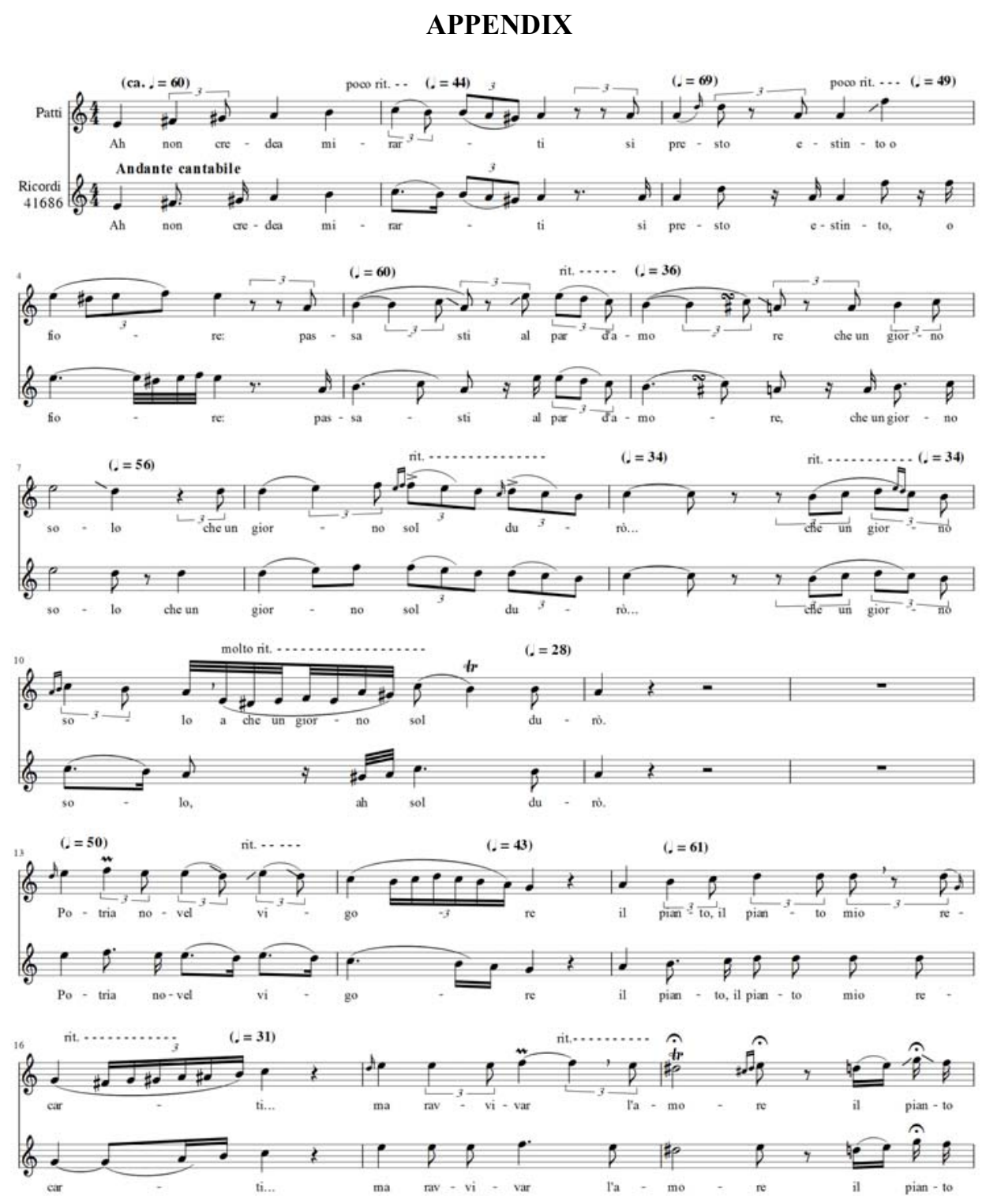

Figure 1. "Ah! non credea," bars 1-18. Patti indulges in a number of ritardandos consistent with the sobbing quality of the text. Contrary to her interpretation of Mozart's arias, this is richly nuanced and generously ornamented. 


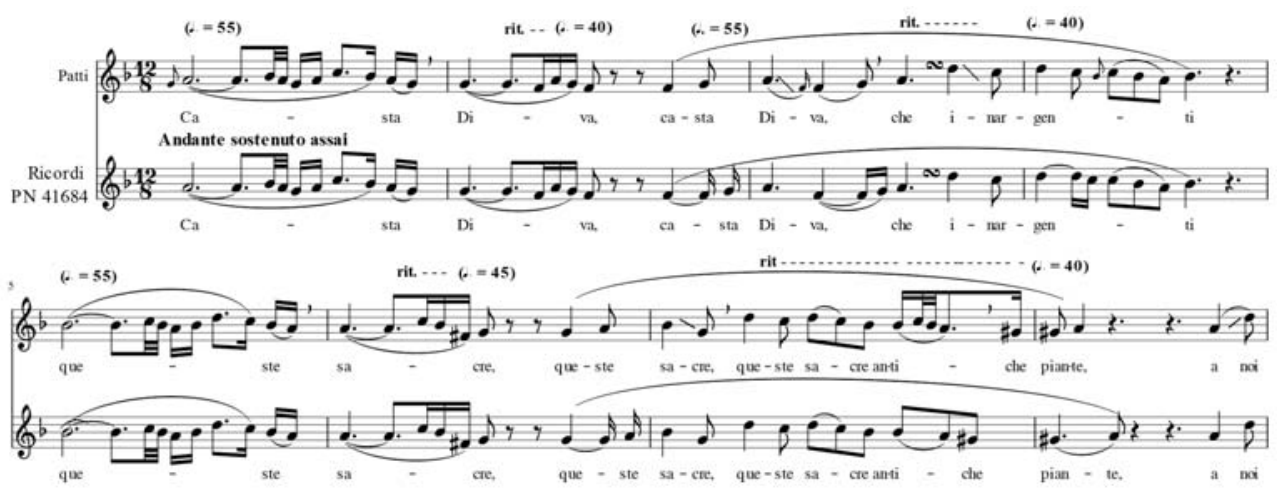

Figure 2. "Casta Diva," bars 1-15. In her invocation to the Moon, Patti slows down slightly at the end of each phrase and semi-phrase. 